\title{
Improvement of infection control services in Jeddah hospitals by program standardization and continuous auditing
}

\author{
MA Halwani", NA Tashkandi, NY Nas \\ From International Conference on Prevention \& Infection Control (ICPIC 2011) \\ Geneva, Switzerland. 29 June - 2 July 2011
}

\section{Introduction / objectives}

A proper infection control program in the Ministry of Health's hospitals-Jeddah, Saudi Arabia has never been applied based on focused and aimed scientific plans. The objective of this study was to monitor the enforcement of a scientifically based infection prevention and control program via continuous auditing.

\section{Methods}

A standardization and continuous auditing program was implemented in the year 2009 in twelve hospitals. Three auditing visits were conducted throughout this year to estimate hospital-wide compliance of the required procedures and strategies using auditing sheets based on that year's target aims.

\section{Results}

The first compliance rate for the first visit in the first year was $42 \%$ which increased to $66 \%$ during the second visit and to $78 \%$ during the third visit. During the first audit there were deficiencies in: general measures in infection control (43\%), surveillance (31\%), monitoring of infection control guidelines (81\%), isolation practice (64\%), infection control committee performance (66\%) and education (46\%). These deficiencies improved during the second audit as follows: (37\%), (24\%), (39\%), (21\%), (49\%) and (25\%) respectfully. During the third audit, deficiencies were as follows: (32\%), (22\%), (22\%), (14\%), (34\%) and (9\%) respectfully.

\section{Conclusion}

A standardized infection control program for ongoing monitoring led to a significant improvement in infection

The Administration of Infection Control, Health Affairs, Jeddah, Saudi Arabia control practices in all twelve hospitals in Jeddah. Consequently, these results might suggest that such a program can be applied to other Ministry of Health hospitals in the Kingdom.

\section{Disclosure of interest}

None declared.

Published: 29 June 2011

doi:10.1186/1753-6561-5-S6-P275

Cite this article as: Halwani et al:: Improvement of infection control services in Jeddah hospitals by program standardization and continuous auditing. BMC Proceedings 2011 5(Suppl 6):P275.

Submit your next manuscript to BioMed Central and take full advantage of:

- Convenient online submission

- Thorough peer review

- No space constraints or color figure charges

- Immediate publication on acceptance

- Inclusion in PubMed, CAS, Scopus and Google Scholar

- Research which is freely available for redistribution 